\title{
Quantifying Micronutrient (Zn and Fe) Content in Super Elite Accession at Varying Level of Polishing by Using X-Ray Fluorescence in Rice Grain Grown under Aerobic Condition
}

\author{
Himanshu Pandey ${ }^{1 *}$, H.E. Shashidhar ${ }^{1}$, Samriti $^{2}$ and Pramod Sharma ${ }^{3}$ \\ ${ }^{1}$ Department of Plant Biotechnology, University of agricultural science, GKVK Bangalore, India \\ ${ }^{2}$ Department of Biotechnology, Dr. Yashwant Singh Parmar University of Horticulture and \\ Forestry, Nauni, Solan, Himachal Pradesh 173230, India \\ ${ }^{3}$ Department of Seed Science, Yashwant Singh Parmar University of Horticulture and Forestry, \\ Nauni, Solan, Himachal Pradesh 173230, India \\ *Corresponding author
}

\section{A B S T R A C T}

Iron and zinc are essential micronutrients for both plant productivity and nutritional

Ke ywords

Rice,

Iron,

Zinc,

Micronutrients

and X-ray

fluorescence.

Article Info

Accepted:

04 June 2017

Available Online:

10 July 2017 quality. Although $\mathrm{Fe}$ is the most abundant transitional metal in the world, its chemical properties hinder its availability to plants. The research aimed to compare different genotypes of aerobic rice for their iron and zinc content and measures their comparative losses among different genotypes, from brown to white rice. Quantification of Fe and $\mathrm{Zn}$ was estimated by using X-Ray Fluorescence Spectroscopy in brown and white rice. A significant difference was observed in loss of both micronutrients from brown to white rice. AM-72 had highest $\mathrm{Fe}$ and $\mathrm{Zn}$ content in brown rice and highest Fe content in polished rice whereas, IRJS-107 had highest $\mathrm{Zn}$ content in white rice. Lowest count of $\mathrm{Zn}$ content in case of both brown and white rice was recorded in BJ-23. Sebati and ARB-6 had lowest Fe content in brown and white rice respectively. Positive correlation was observed between $\mathrm{Fe}$ and $\mathrm{Zn}$ content. White rice was deficient in both essential nutrients Fe and $\mathrm{Zn}$. The loss of micronutrients from brown rice to white rice was above $50 \%$ of $\mathrm{Fe}$ and approximately $30 \%$ to $50 \%$ of $\mathrm{Zn}$. There was a greater quantitative and cumulative loss in Fe content than $\mathrm{Zn}$, suggesting that Fe is present comparatively more in the outer aleurone layer than $\mathrm{Zn}$.

\section{Introduction}

Rice is a member of the Poaceae family belonging to the genus Oryza. This genus includes twenty undomesticated and two domesticated species (cultigens). Feral species of rice are widely dispersed in the humid tropics and subtropics of Africa, Asia, Central and South America, and Australia (Chang, 1985). Among the two cultivated species, African rice (O. glaberrima Steud.) is restrained to West Africa, whereas, Asian rice (O. sativa L.) is now commercially being cultivated across 112 countries, covering all continents (Bertin et al., 1971). The data are evident to prove that rice is the basic food for most of the area around the world. Rice is an important source of carbohydrate but it is lacking in fat, protein and micronutrient. The content of carbohydrates is measured roughly 
around $80 \mathrm{~g}$, fat with $0.66 \mathrm{~g}$ and protein with $7.13 \mathrm{~g}$ per $100 \mathrm{~g}$ of rice. The remaining vitamins and minerals are found in traces. One of the important mineral nutrients is $\mathrm{Fe}$ with approximately $0.80 \mathrm{mg}$ per $100 \mathrm{~g}$ of rice which is not sufficient enough for proper growth and development of human who depend upon rice as their staple food (Ibrahim et al., 2013). Iron plays a determining role for proper functioning of various enzymes and proteins by acting as a cofactor for such proteins and enzymes like cytochrome b6f, FAD, Fe-S complex in photosynthesis and some components of blood. So Iron deficiency is the most common nutritional deficiency in the world (Soetan et al., 2010).

Zinc is involved in synthesis of many enzymes critical to cellular growth and differentiation. While mild to moderate Zinc deficiency is common throughout the world, one third of the population is at high risk in low income countries according to the international zinc nutrition consultative group (http://www.izinc.org.in).

Zinc deficiency leads to impaired growth, immune dysfunction, increased morbidity and mortality, adverse pregnancy outcome and abnormal neurobehavioral development.

Zinc is directly related to the severity and frequency of diarrhoeal episodes, a major cause of child death.

These bodies of evidences on zinc deficiency have accumulated to the degree that zinc fortification has been jointly recommended by WHO and FAO. Hence iron and zinc supplements are used in food fortification programs to combat IDA (iron deficiency anaemia). Utilization of biofortification techniques for creation of staple food crops with increased bioavailable iron has become a common tool in area of high $\mathrm{Fe}$ varieties of rice.

\section{Materials and Methods}

$\mathrm{Zn}$ and Fe content was estimated in the paddy collected from the ten genotypes (Table 1) grown in the field. Grains of individual lines were harvested manually and hand threshed to avoid any contamination. Unbroken, uniform grains were taken for consideration and dehusking and hydrochloric acid treatment was not followed in this particular method. The $\mathrm{Zn}$ and $\mathrm{Fe}$ content in paddy was calculated from X-ray fluorescence (XRF) at ICRISAT, Hyderabad. Estimation is conducted in both Brown and polished rice.

\section{Results and Discussion}

All selected genotypes restrain high $\mathrm{Fe}$ and $\mathrm{Zn}$ in brown rice contrast to white rice. Attempt was made to understand the reason of loss from brown to white rice and the possible reason found was that polishing of brown rice causes leaching of nutrient and leads to decrease in content of $\mathrm{Fe}$ and $\mathrm{Zn}$. The order of high $\mathrm{Fe}$ and $\mathrm{Zn}$ includes bran (embryo + aleurone layer) $>$ hull $>$ whole grain $>$ brown rice > polished rice (endosperm) as per studies conducted by Lu et al., (2013) and similar result were obtained from this studies. The content of iron and zinc for both brown and white rice are experimentally comparable with the work done earlier by Jorhem et al., (2008). The Iron and Zinc in brown rice ranged from 6.7 to $11.10 \mathrm{mg} \mathrm{kg}^{-1}(\mathrm{Fe}), 18.8$ to $24.4 \mathrm{mg} \mathrm{kg}^{-1}(\mathrm{Zn})$ respectively on the other hand white rice ranges from $1.95-3.65 \mathrm{mg} \mathrm{kg}^{-1}$, $17.30-20.95 \mathrm{mg} \mathrm{kg}^{-1}$.

Evaluation of mean for performance of iron and zinc suggest that AM-72 showed highest $\mathrm{Fe}$ and $\mathrm{Zn}$ for brown rice but IRJS-107 exhibited maximum zinc content after polishing. Sebati presented lowest Fe content in brown rice but in case of polished rice finding revealed the lowest content in BI-33 (Figs.1 and 2). 
Iron and Zinc contents in brown and white rice grain for selected genotypes were estimated using XRF in ICRISAT at harvest plus unit, Hyderabad. The $t$ test was performed at (5\% level of significance) to check the significant loss of iron and zinc content from brown rice to white rice in ten selected genotypes. The $p$ value for the loss of $\mathrm{Fe}$ and $\mathrm{Zn}$ from brown rice to white rice was observed as $1.2516 \times 10^{-7 *}$ and $1.9 \times 10^{-6 *}$ respectively.

Fig.1 Fe content in brown and polished rice using XRF

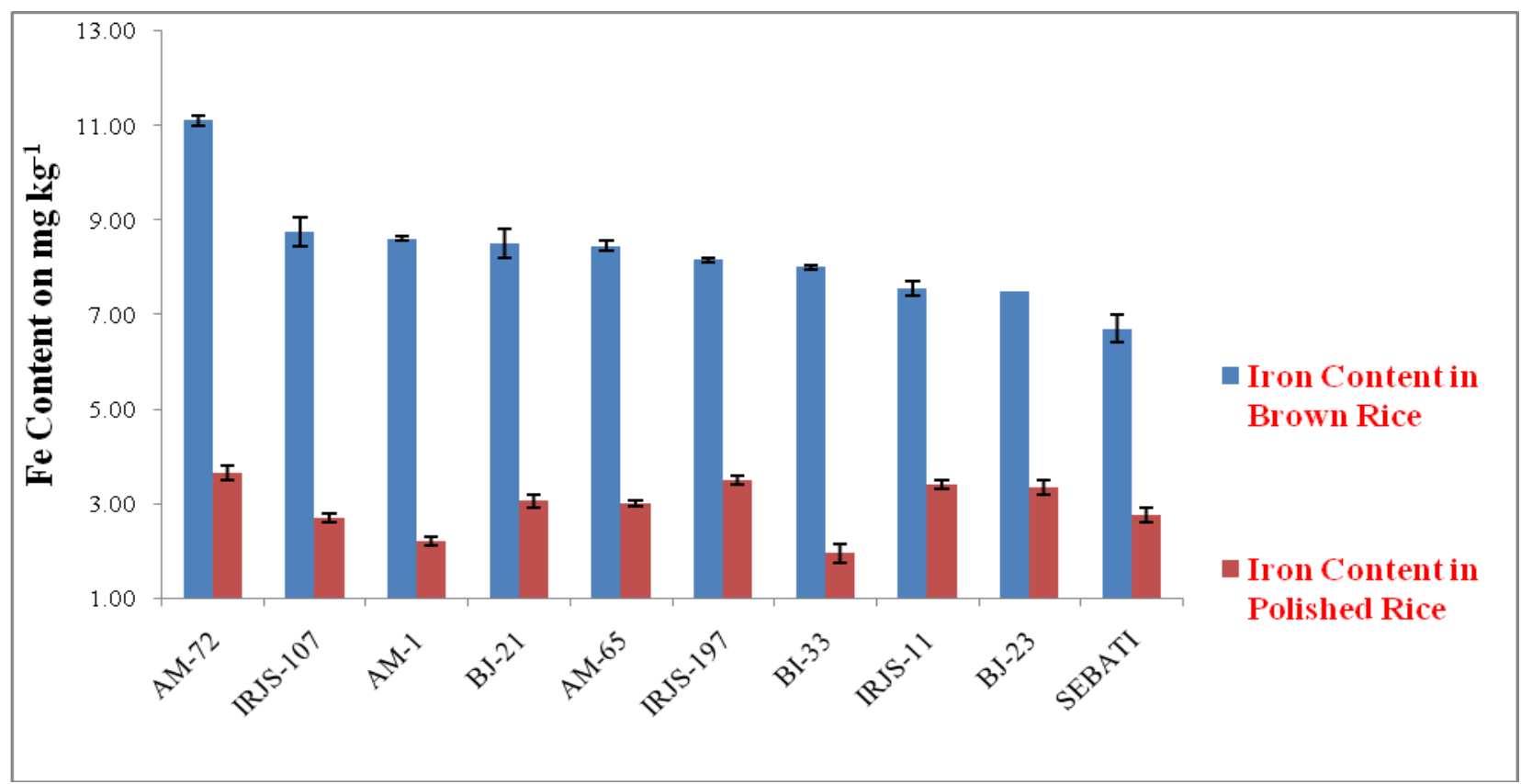

Fig.2 Zinc content in brown and polished rice using XRF

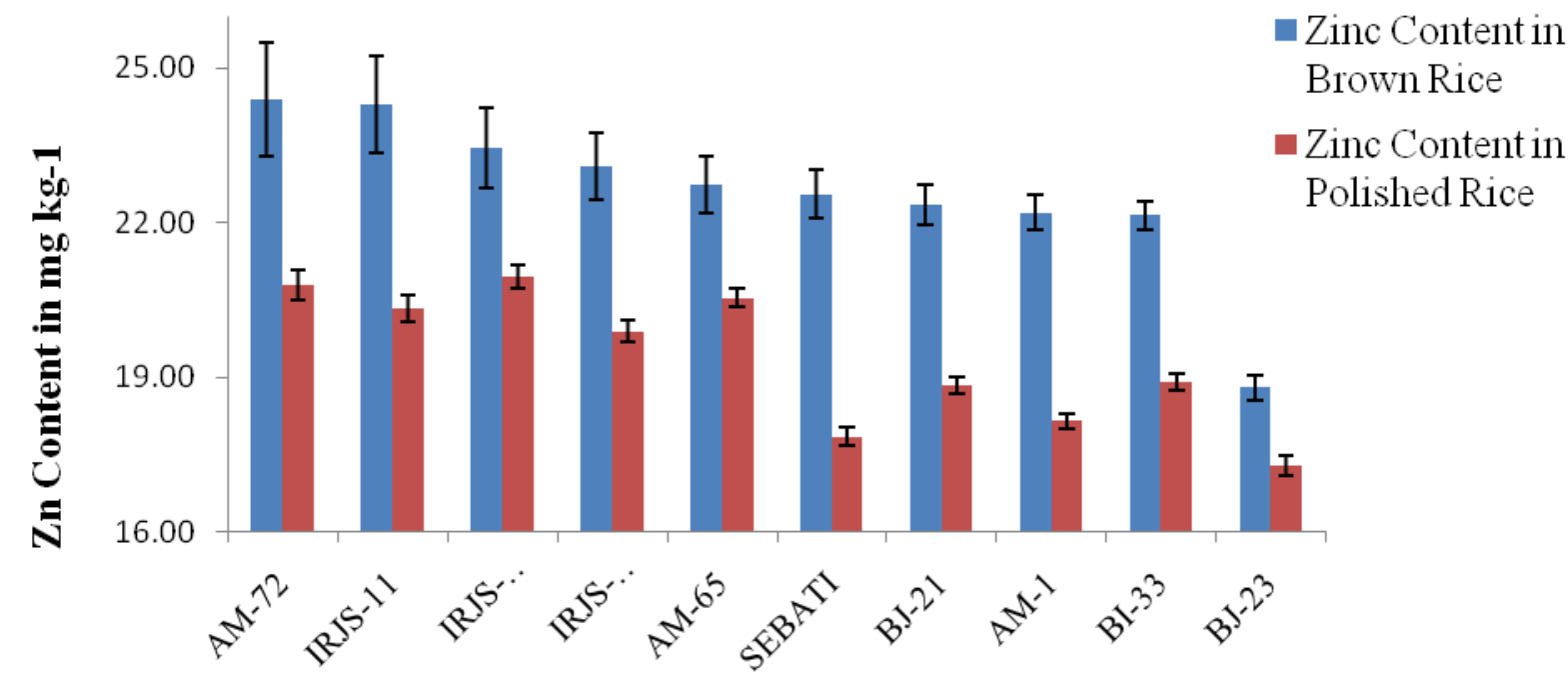


Fig.3 Extent of loss in $\mathrm{Fe}$ content from brown to polished rice

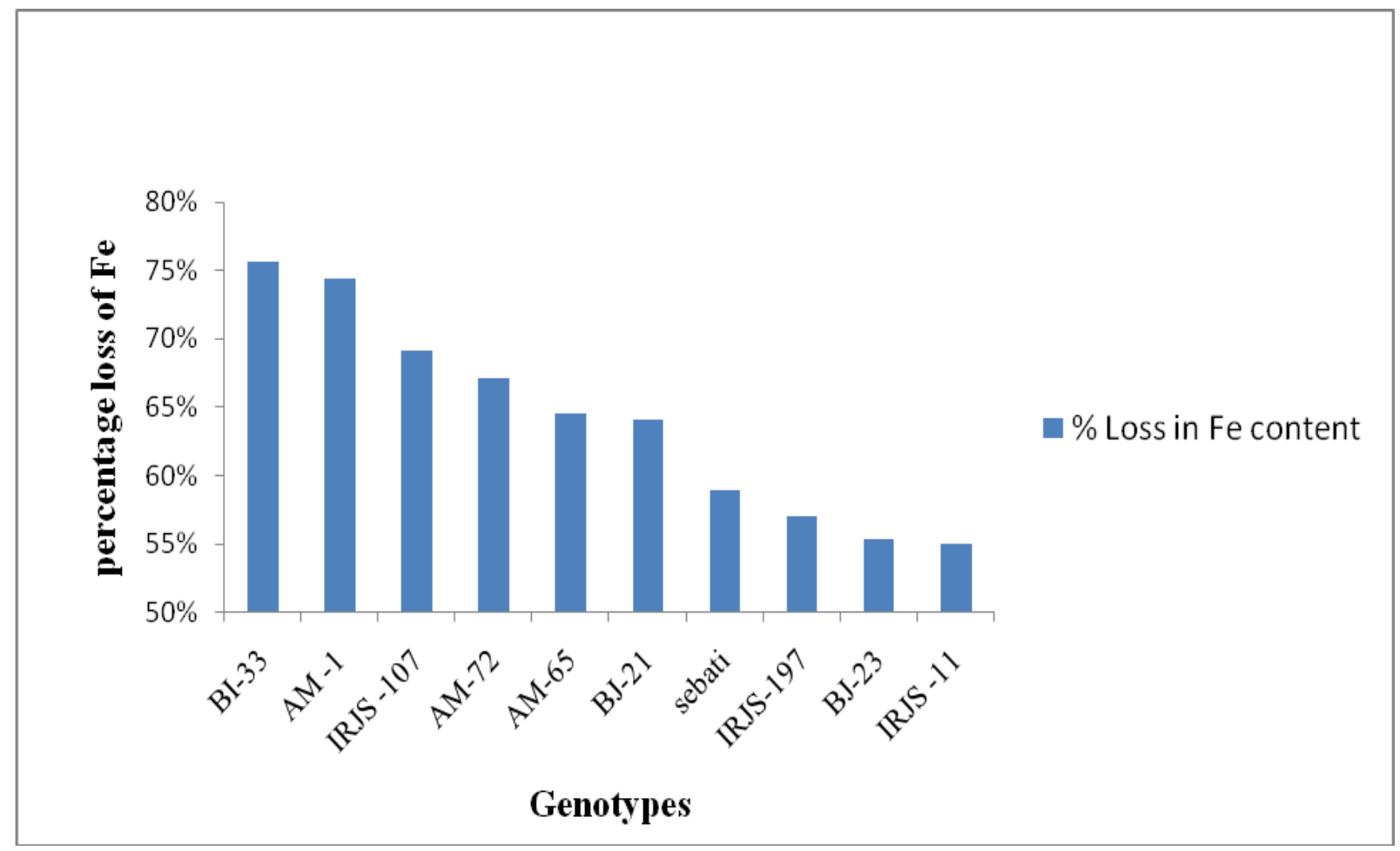

Fig.4 Extent of loss in $\mathrm{Zn}$ from brown to polished rice

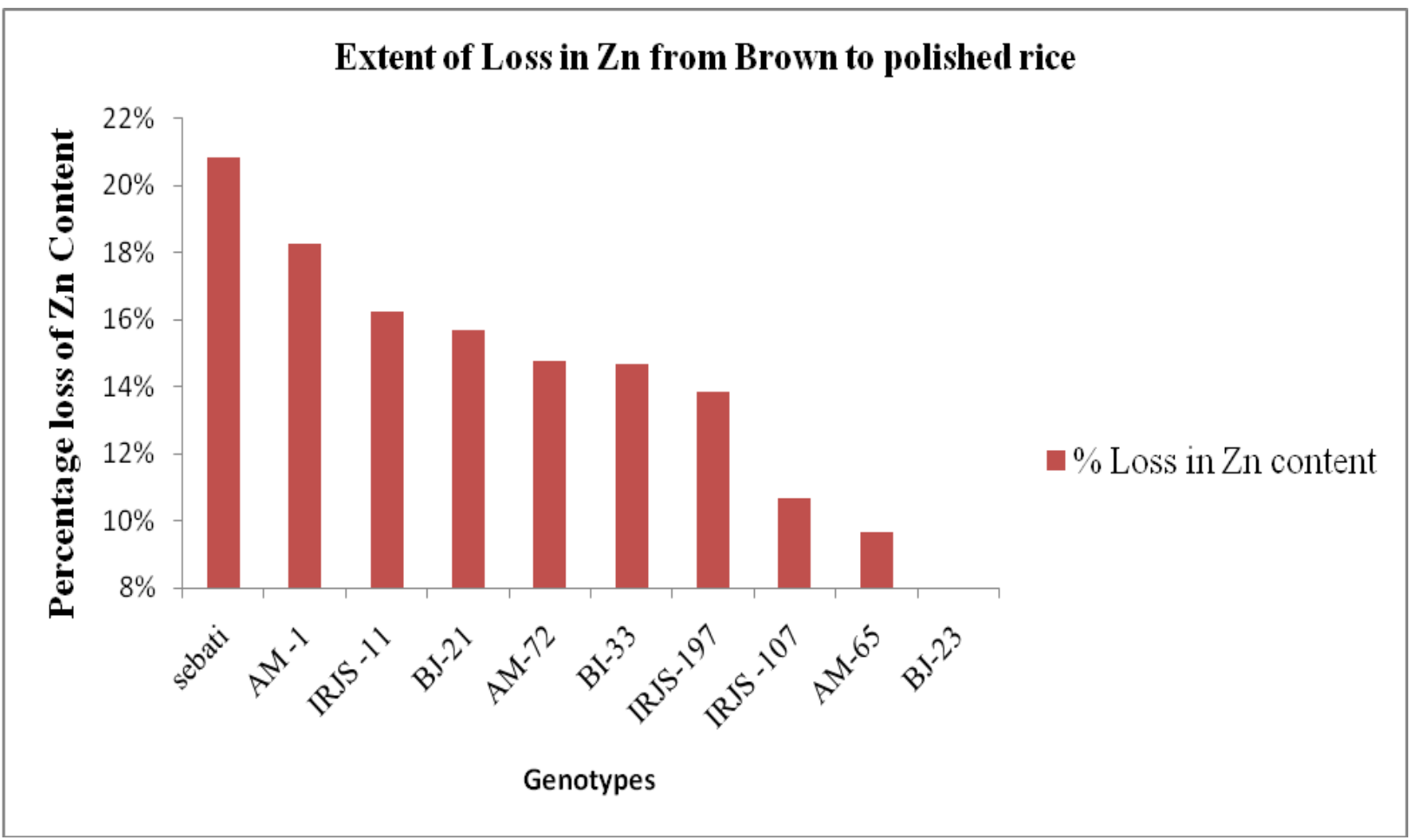


Fig.5 Correlation between iron and zinc content between brown and white rice

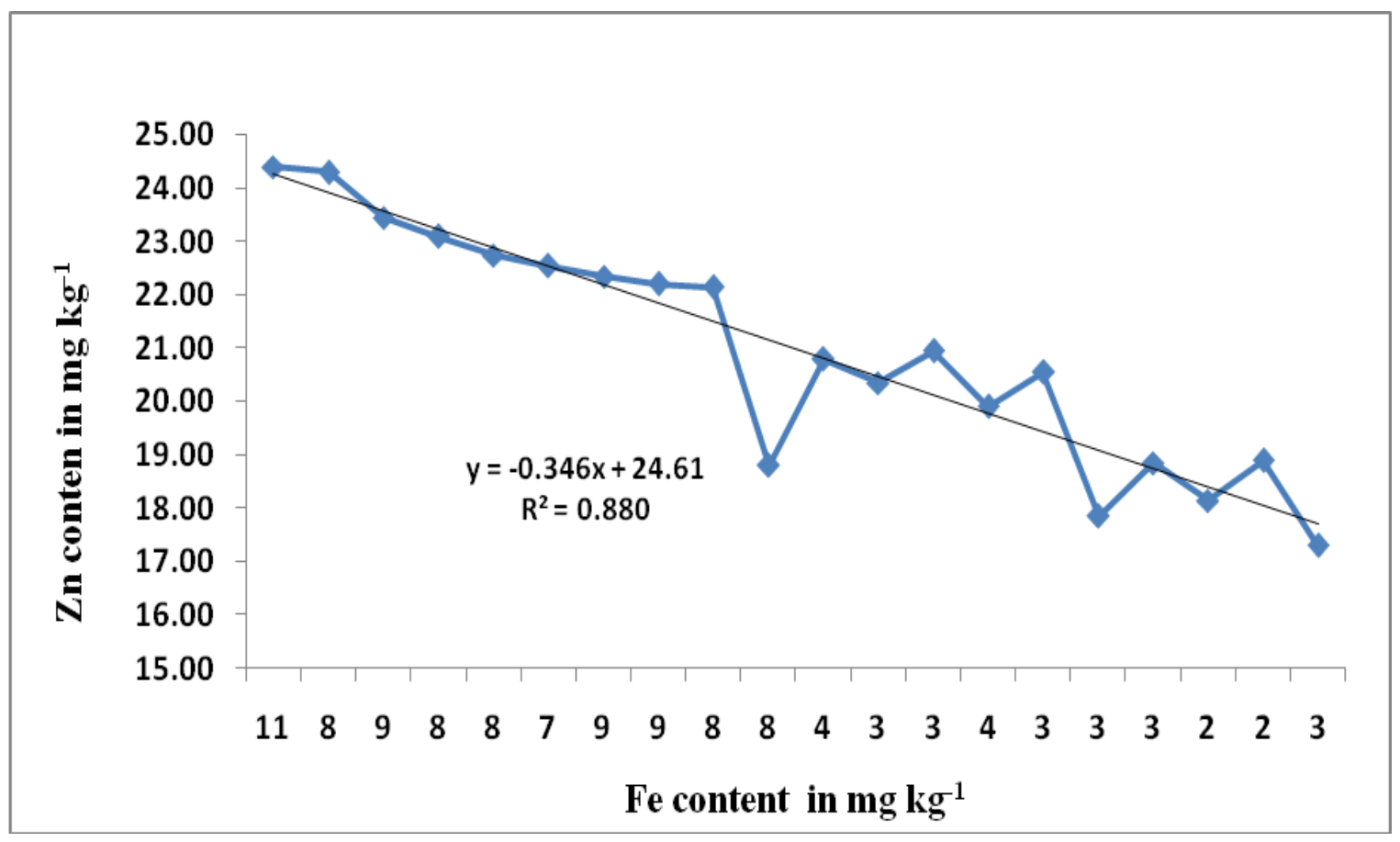

Table.1 List of super elite accessions used in experiment

\begin{tabular}{|l|l|}
\hline Different genotypes of rice & Parentage \\
\hline AM-1 & Azucena x Moromutant \\
\hline AM-65 & Azucena x Moromutant \\
\hline AM-72 & Azucena x Moromutant \\
\hline BJ-21 & Budda $x$ jeerigesanna \\
\hline BJ-23 & Budda x jeerigesanna \\
\hline BI-33 & Budda x IR64 \\
\hline IRJS-11 & IR64xjeerigesanna \\
\hline IRJS-107 & IR64xjeerigesanna \\
\hline IRJS-197 & IR64x jeerigesanna \\
\hline Sebati & Improved Variety \\
\hline
\end{tabular}


Table. $2 \mathrm{Fe}$ and $\mathrm{Zn}$ content in experiment rice varieties

\begin{tabular}{|c|c|c|c|c|c|c|c|c|c|c|c|c|}
\hline \multirow{2}{*}{ VARIETIES } & \multicolumn{3}{|c|}{$\begin{array}{c}\text { Brown Rice - Fe Content } \\
\left(\mathrm{mg} \mathrm{kg}^{-1}\right)\end{array}$} & \multicolumn{3}{|c|}{$\begin{array}{c}\text { White Rice - Fe Content } \\
\left(\mathrm{mg} \mathrm{kg}^{-1}\right)\end{array}$} & \multicolumn{3}{|c|}{$\begin{array}{c}\text { Brown rice }-\mathrm{Zn} \text { content } \\
\left(\mathrm{mg} \mathrm{kg}^{-1}\right)\end{array}$} & \multicolumn{3}{|c|}{$\begin{array}{l}\text { White rice }-\mathrm{Zn} \text { content } \\
\left(\mathrm{mg} \mathrm{kg}^{-1}\right)\end{array}$} \\
\hline & $\begin{array}{l}\text { mean } \\
\text { content }\end{array}$ & $\begin{array}{l}\text { Standard } \\
\text { Deviation }\end{array}$ & $\begin{array}{l}\text { Standard } \\
\text { Error }\end{array}$ & $\begin{array}{l}\text { mean } \\
\text { content }\end{array}$ & $\begin{array}{l}\text { Standard } \\
\text { Deviation }\end{array}$ & $\begin{array}{l}\text { Standard } \\
\text { Error }\end{array}$ & $\begin{array}{l}\text { mean } \\
\text { content }\end{array}$ & $\begin{array}{l}\text { Standard } \\
\text { Deviation }\end{array}$ & $\begin{array}{l}\text { Standard } \\
\text { Error }\end{array}$ & $\begin{array}{l}\text { mean } \\
\text { content }\end{array}$ & $\begin{array}{l}\text { Standard } \\
\text { Deviation }\end{array}$ & $\begin{array}{l}\text { Standard } \\
\text { Error }\end{array}$ \\
\hline AM- 1 & 8.60 & 0.42 & 0.30 & 2.20 & 0.14 & 0.10 & 22.20 & 0.28 & 0.20 & 18.15 & 0.21 & 0.15 \\
\hline AM-65 & 8.45 & 0.21 & 0.15 & 3.00 & 0.14 & 0.10 & 22.75 & 0.35 & 0.25 & 20.55 & 0.49 & 0.35 \\
\hline AM-72 & 11.10 & 0.42 & 0.30 & 3.65 & 0.21 & 0.15 & 24.40 & 0.14 & 0.10 & 20.80 & 0.14 & 0.10 \\
\hline BI- 33 & 8.00 & 0.14 & 0.10 & 1.95 & 0.07 & 0.05 & 22.15 & 1.20 & 0.85 & 18.90 & 0.14 & 0.10 \\
\hline BJ- 21 & 8.50 & 0.14 & 0.10 & 3.05 & 0.21 & 0.15 & 22.35 & 0.49 & 0.35 & 18.85 & 0.21 & 0.15 \\
\hline BJ-23 & 7.50 & 0.00 & 0.00 & 3.35 & 0.21 & 0.15 & 18.80 & 0.14 & 0.10 & 17.30 & 0.56 & 0.40 \\
\hline IRJS- 11 & 7.55 & 0.07 & 0.05 & 3.40 & 0.14 & 0.10 & 24.30 & 0.28 & 0.20 & 20.35 & 0.21 & 0.15 \\
\hline IRJS-107 & 8.75 & 0.07 & 0.05 & 2.70 & 0.14 & 0.10 & 23.45 & 0.07 & 0.05 & 20.95 & 0.07 & 0.05 \\
\hline IRJS-197 & 8.15 & 0.07 & 0.05 & 3.50 & 0.28 & 0.20 & 23.10 & 0.70 & 0.50 & 19.90 & 0.14 & 0.10 \\
\hline Sebati & 6.70 & 0.42 & 0.30 & 2.75 & 0.21 & 0.15 & 22.55 & 0.21 & 0.15 & 17.85 & 0.07 & 0.05 \\
\hline
\end{tabular}


It clearly indicates that a considerable loss of $\mathrm{Fe}$ and $\mathrm{Zn}$ occurred during the polishing process of brown rice to white rice.

The experimental findings indicate that white rice is having less mineral content then brown rice as shown in figures 3 and 4 . This loss could be because of the expression of transporter responsible for moving nutrient inside the endosperm is less as compared to aleuron layer (Wirth et al., 2009) and basically studies say that endosperm of rice is starchy so it has less content of minerals like Iron and Zinc (Johnoson et al., 2011). The correlation studies were conducted to find the out the association for iron and zinc content in brown and white rice.

The correlation was positive with a value of 0.80 which clearly indicated that iron and zinc are having interrelationship that is the more the iron the more the zinc content vice versa as proved by earlier work done by White et al., (2005). The preliminary findings suggested that AM-72 showed highest Fe and Zn for brown rice but high $\mathrm{Zn}$ content was found in IRJS-107 for polished rice.

BJ-23 showed lowest Zinc content in brown and white rice. Lowest $\mathrm{Fe}$ content for polished rice was observed in genotype BI-33 as represented in figure 5.

\section{References}

Chang, T. T. (1985). Crop history and genetic conservation: rice: a case study. Iowa State J Res., (USA).

Bertin, J. (1971). Atlas of food crops (No. 581.9
A8).

Ibrahim, N. D., Bhadmus, Z., and Singh, A. (2013). Hydro-priming and Re-drying effects on germination, emergence and growth of upland rice (Oryza sativa L.). Nigerian Journal of Basic and Applied Sciences, 21(2), 157-164.

Soetan, K. O., Olaiya, C. O., and Oyewole, O. E. (2010). The importance of mineral elements for humans, domestic animals and plants-A review. Afr. J. Food Sci., 4(5), 200-222.

Lu, L., Tian, S., Liao, H., Zhang, J., Yang, X., Labavitch, J. M., and Chen, W. (2013). Analysis of metal element distributions in rice (Oryza sativa L.) seeds and relocation during germination based on $\mathrm{X}$-ray fluorescence imaging of $\mathrm{Zn}, \mathrm{Fe}, \mathrm{K}, \mathrm{Ca}$, and Mn. PLoS One, 8(2), e57360.

Jorhem, L., Becker, W., and Slorach, S. (1998). Intake of 17 elements by Swedish women, determined by a 24-h duplicate portion study. J. Food Composition Anal., 11(1), 32-46.

Wirth, J., Poletti, S., Aeschlimann, B., Yakandawala, N., Drosse, B., Osorio, S. and Sautter, C. (2009). Rice endosperm iron biofortification by targeted and synergistic action of nicotianamine synthase and ferritin. Plant Biotechnol. J., 7(7), 631-644.

Johnson, A. A., Kyriacou, B., Callahan, D. L., Carruthers, L., Stangoulis, J., Lombi, E., and Tester, M. (2011). Constitutive overexpression of the OsNAS gene family reveals single-gene strategies for effective iron-and zinc-biofortification of rice endosperm. PLoS One, 6(9), e24476.

White, P. J., and Broadley, M. R. (2005). Biofortifying crops with essential mineral elements. Trends Plant Sci., 10(12), 586593.

\section{How to cite this article:}

Himanshu Pandey, H.E. Shashidhar, Samriti and Pramod Sharma. 2017. Quantifying Micronutrient ( $\mathrm{Zn}$ and $\mathrm{Fe}$ ) Content in Super Elite Accession at Varying Level of Polishing by Using X-Ray Fluorescence in Rice Grain Grown under Aerobic Condition. Int.J.Curr.Microbiol.App.Sci. 6(7): 1-7. doi: https://doi.org/10.20546/ijcmas.2017.607.001 